\title{
Youth Unemployment, Labor Market Transitions, and Scarring: Evidence from Bosnia and Herzegovina, 2001-04
}

\author{
Jean Fares and Erwin R. Tiongson \\ The World Bank
}

\begin{abstract}
Relatively little is known about youth unemployment and its lasting consequences in transition economies, despite the difficult labor market adjustment experienced by these countries over the last decade. This paper examines early unemployment spells and their longer-term effects among the youth in Bosnia and Herzegovina $(\mathrm{BiH})$, where the labor market transition is made more difficult by the challenges of a post-conflict environment. This paper uses panel data covering up to 4,800 working-age individuals over the 2001 to 2004 period. There are three main findings from the analysis: First, youth unemployment is high, about twice the national average, consistent with recent findings from the $\mathrm{BiH}$ labor market study. Younger workers are more likely to go into inactivity or unemployment and are also less likely to transition out of inactivity, holding other things constant. Second, initial spells of unemployment or joblessness appear to have lasting adverse effects on earnings and employment ("scarring”). There is no evidence, however, that the youth are at a greater risk of scarring, or suffer disproportionately worse outcomes from initial joblessness, compared to other age groups. Third, higher educational attainment is generally associated with more favorable labor market outcomes. Skilled workers are less likely to be jobless and are less likely to transition from employment into joblessness. However, there is evidence that the penalty from jobless spells may also be higher for more educated workers. We speculate that this may be due in part to signaling or stigma, consistent with previous findings in the literature.
\end{abstract}

JEL Classification number: J13, J64, J31

Keywords: youth unemployment, transition probability, wage scarring

World Bank Policy Research Working Paper 4183, April 2007

The Policy Research Working Paper Series disseminates the findings of work in progress to encourage the exchange of ideas about development issues. An objective of the series is to get the findings out quickly, even if the presentations are less than fully polished. The papers carry the names of the authors and should be cited accordingly. The findings, interpretations, and conclusions expressed in this paper are entirely those of the authors. They do not necessarily represent the view of the World Bank, its Executive Directors, or the countries they represent. Policy Research Working Papers are available online at http://econ.worldbank.org. 


\section{Introduction}

Young people everywhere experience considerable difficulties entering the labor market. On average, across regions, youth unemployment is about 2 to 3 times the national unemployment rate. Youth unemployment is typically concentrated among the less educated workers, but in some labor markets the unemployment rate is high even among the most educated workers.

While such unemployment spells may be temporary, and the associated income loss also short-lived, there is some evidence that the consequences of these early unemployment spells may impose enduring disadvantages on individual workers. Over the last two decades a growing literature has emerged on the post-unemployment labor market disadvantage of youth, or what is otherwise known as a labor market "scar." Following an initial experience of unemployment, many individuals have been found to be vulnerable to new rounds of unemployment ("unemployment scar"), lower postunemployment wages ("wage scar”), or both.

Much of this literature has been drawn from labor market experiences in advanced economies (e.g., OECD 1998, Gregg and Tominey 2005, Arulampalam 2000). Much less is known about scarring in transition economies, where unemployment and labor market adjustment have been prominent public policy issues following the early transition period but where little is known about their lasting consequences. ${ }^{1}$ In large part, this has been due to the relative scarcity of longitudinal data.

This note examines early unemployment spells and their longer-term effects among the youth in Bosnia and Herzegovina. It uses data drawn from the Living in $\mathrm{BiH} /$ Living Standards Measurement Survey (LSMS), a rare, longitudinal database covering up to 4,800 working-age individuals over the 2001 to 2004 period. It documents the labor market outcomes of individuals up to three years after the initial period, and estimates their covariates.

The rest of the note is organized as follows: Section II provides a brief survey of the literature on youth unemployment and scarring. Section III discusses the data sources and the descriptive statistics. Section IV presents the empirical framework and reports the main results. Section V summarizes the findings and provides some concluding observations.

\section{Brief Review of Related Literature}

Many young men and women face significant difficulties entering the labor market. According to most measures, youth are more likely to be unemployed than adults, although significant variations in unemployment exist between urban and rural sectors, between developed and developing countries, as well as between poor and rich

\footnotetext{
${ }^{1}$ One important exception is a recent study of Hungary (Audas and others 2005). There have also been studies of labor market transitions in former socialist economies (see Boeri and Terrell 2002 for a brief survey of the literature).
} 
households. There are variations based on gender as well: Young women are more likely than young men to be unemployed and to stay out of the labor force entirely.

\section{Youth unemployment rates}

Youth currently constitute a quarter of the working-age population worldwide, of which some 47 percent are unemployed. According to estimates drawn from the ILO, the global unemployment rate for youth has increased steadily over the last 10 years, from 11.7 percent in 1993 to 14.4 percent in $2003 .^{2}$ Youth unemployment rates vary widely across regions, from a low of 7 percent in East Asia to 13.4 percent in industrial economies to a high of 25 percent in the Middle East and North Africa. ${ }^{3}$ Furthermore, there is considerable cross-country variation, not only in the levels of youth unemployment but also in the ratio of the youth to adult unemployment rate. A very high ratio in some countries is usually taken as a signal of atypical youth difficulties in the transition to work, a clear source of concern for policymakers.

Table 1. Average Unemployment and Jobless Rates for Youth: Selected Countries in Europe \& Central Asia

\begin{tabular}{lcc}
\hline & Unemployment & Jobless \\
& & \\
\hline Adult & 11 & 21 \\
Youth & 21 & 24 \\
of which: & & \\
Male & 22 & 22 \\
Female & 21 & 26 \\
Urban & & \\
Rural & 22 & 22 \\
& 23 & 24 \\
\hline
\end{tabular}

Source: Authors calculations based on available household survey data.

Across all markets, youth unemployment rate is typically 2 to 3 times higher than the adult unemployment rate, regardless of the aggregate level of unemployment. In the Europe and Central Asia (ECA) region, the average unemployment rate for youth is 21 percent, about twice as high the unemployment rate of adults. The jobless rate, which includes the unemployed as well as the discouraged youth, is estimated to be as high as 24 percent. The youth jobless rate is higher among females (26 percent) and in rural areas (24 percent). O'Higgins (2004) shows that transition countries in Europe, nowhere is the youth unemployment rate lower than 10 percent. In fact, in Bulgaria, Croatia, Poland and Slovakia it is over 35 percent. In 2002, the ratio of youth to adult unemployment rate was found to be just under 2-to-1 in EU countries, while in the EU

\footnotetext{
${ }^{2}$ See ILO (2004). The ILO produces global and regional estimates based on several national surveys and the ILO Global Employment Trends model.

${ }^{3}$ See ILO (2004).
} 
accession countries it was 2.2. More generally the ratio tends to be higher in Southern Europe.

Kolev and Saget (2005) provide evidence from countries in South East Europe (SEE) that over a decade after the start of transition period and despite economic recovery in most countries in the region, the employment prospects for young workers still remain dismal. They find that the average youth unemployment rate was over twice the European Union average, and thrice the average adult unemployment rate. Together with high youth unemployment rates, Kolev and Saget (2005) also report the growth of pools of jobless young workers not looking for work and the rising numbers of young workers working in unprotected environments.

O’Higgins (2004) observes that in Poland, Hungary, Czech Republic and the Slovak Republic, the incidence of long-term unemployment among the youth is large and not much lower than the long-term incidence of unemployment among adults. In other countries in Latin America, Eastern Europe, and in the former Soviet Union, evidence from longitudinal data also suggests that young workers experience sustained spells of unemployment. ${ }^{4}$

\section{Consequences of youth unemployment}

Does the initial experience of unemployment lead to permanent labor market disadvantage among the youth? The existing empirical evidence is drawn mostly from the experiences of advanced economies. It is also, in large part, inconclusive. In the United States, most studies find that spells of unemployment after leaving school do not result in persistent unemployment later in life. This corresponds to fairly high transition rates from unemployment into employment: 46 percent of unemployed youth are employed one month later. The corresponding transition rates in France, Germany, and the United Kingdom are much lower, ranging from 4 to 14 percent, and there is more evidence that early unemployment leads to persistent unemployment. One-third of the unemployed in France have been unemployed more than a year, compared with 8.5 percent in the United States (Ryan 2001).

The adverse effects of early unemployment spells on subsequent employment outcomes and employment stability have been found to persist for as long as seven years in France, compared with only two years in the United States (Ryan 2001). The degree of persistence appears to be responsive to business cycles; that is, where the local economy is experiencing job growth, the adverse consequences of early unemployment seems less permanent. Early analysis using longitudinal data from the United States (Corcoran 1982 and Ellwood 1982) show that foregone participation lowers future wages. In addition, Burgess et al (2003), using British data, show that the scarring effect of early unemployment tends to be greatest for the least educated and disadvantaged youth.

\footnotetext{
${ }^{4}$ Borgarello and others (2005). The countries covered include Albania, Argentina, Georgia, Hungary, Poland, Russia, Ukraine, and Venezuela.
} 
A separate strand of the literature focuses on displaced workers and examines the consequences of layoffs on subsequent employment and wage outcomes. Kletzer and Fairlie (2003) analyze NLSY79 data and conclude that the wage disparity between displaced workers and their non-displaced counterparts persists through the five years following displacement. In general, the effect of displacement on workers can be explained by the loss of firm-specific human capital, ${ }^{5}$ and most studies find that the effects of displacement are largest among older workers. For example, again using US data, Jacobson et al (2003) find that longer term adverse effects of displacement tend to be smaller for younger workers. Topel (1990) finds that wages among young displaced workers subsequently converge to the wages of their non-displaced counterparts. In the United Kingdom, Gregory and Jukes (2001) find that while risk of unemployment is lowest among prime age and the highest paid men, the wage penalty for experiencing unemployment is lowest among young men and the low paid, namely, those who have the least firm-specific human capital to lose.

A recent literature explores how, in the presence of asymmetric information, previous unemployment spells might act as a signaling device to reveal information on the quality of workers to future employers. For example, Gibbons and Katz (1991) develop a signaling model in which employers obtain information about the productivity of their workers based on previous experience in the labor market. They test their model using data on displaced workers from the United States. They find that selective lay offs that are not due to plants shut down contain information about workers' productivity. These workers, in turn, suffer larger costs than workers who are displaced due to a plant closure. This signaling model is supported by data from Canada's survey of displaced workers (Doiron 1995). In Italy, Lupi and Ordine (2002) find that the experience of unemployment in regions with high unemployment rates does not necessarily signal poor worker quality. As a result, unemployment spells in these regions have less adverse implications on future outcomes than in regions with low unemployment rates. This stigma or signaling effect seems to be highest among the most skilled workers, those who are least likely to experience unemployment. For example, Hyytinen and Rouvinen (2006), using data from the European Community Household Panel, show that the adverse effect of temporary spells of unemployment and/or self employment-what they call "the stigma of failure"-is larger for more educated workers compared to the less educated workers.

Initial difficulties in employment experienced by young people may also have consequences outside the labor market. In particular, weak youth labor markets have been observed to delay other life transitions. In Europe, the average age when the youth leave their homes has steadily increased, especially in southern European countries. In Italy, 80 percent of males aged 18-30 still live with their parents, compared with 25 percent in the United States. Across OECD countries, the average age at marriage has increased while the average number of children per household has fallen. Deteriorating conditions in youth labor markets have at least a partial role in explaining these recent changes in life transitions. Youth tend to delay leaving their parents' homes during

\footnotetext{
${ }^{5}$ Becker (1975) seminal contribution to human capital literature makes the distinction between job specific and general human capital.
} 
recessions. Differences in the relative strength of country youth labor markets can explain observed differences across countries in the average age when the youth leave home (Card and Lemieux 2000). In Germany and Spain, the likelihood of leaving home increases significantly with youth employment status and labor earnings (Blanco and Kluve 2002).

As previously noted, much of the literature on the consequences of youth unemployment is drawn from the experiences of advanced economies. The literature has been constrained in large part by the lack of appropriate (panel) data in transition economies. There is one important exception: Audas and others (2005) follow some 3000 young workers in Hungary over the 1994 to 1998 period. Not surprisingly they find a strong state-dependence in labor market status; that is, the labor market status the previous month is a strong predictor of labor market status the following month. They also find that employment in summer is negatively related to the probability of unemployment. In addition, they provide evidence that academic excellence confers an enduring advantage to young workers.

This paper contributes to the nascent literature on youth unemployment in transition economies by focusing on Bosnia and Herzegovina (BiH), where relatively little is known about the labor market, in general, and youth unemployment, in particular. Relatively few relevant empirical studies exist: these include the first labor market study (World Bank 2002); a study of the gender dimensions of the labor market, (Lokshin and Mroz 2003); the labor market chapter of the World Bank’s Country Economic Memorandum ${ }^{6}$; and a recent note on poverty and the labor market (Tiongson and Yemtsov 2006).

An important recent contribution to the literature on youth unemployment is the update of the 2002 labor market study, Labor Market Update: The Role of Industrial Relations (World Bank 2006). The study notes the "exceptionally high” youth unemployment, their difficulty in obtaining formal sector employment, and the rapid increase in the average age of formal sector workers. It proposes a separate youth minimum wage to facilitate their employment in the formal sector. In addition, the study observes that youth unemployment decreases with education, but enrollment rates are low at higher levels of education, much lower than comparable European countries.

We build on these recent findings to examine more in depth the labor market disadvantage of the youth. In the case of Bosnia and Herzegovina, the difficult transition period is made doubly challenging by the post-conflict environment. Thus, while relatively little is known about them, the longer-term consequences of unemployment and inactivity may have an impact not only on individuals' future outcomes in the labor market but also on the longer-term stability of the region. Finally, Bosnia and Herzegovina has a rare, but little used, panel data set, one of the few panel datasets in the region. The availability of this dataset allows us to study systematically youth unemployment and its consequences over a four year period.

\footnotetext{
${ }^{6}$ See World Bank (2005).
} 


\section{Data and Descriptive Statistics}

The longitudinal data used in the analysis are drawn from the Bosnia and Herzegovina 2001 Living Standards Measurement Survey (LSMS) and its subsequent waves, from 2002-2004, otherwise known as the "Living in BiH" Survey. The LSMS was first conducted in September-November 2001, a collective effort by the international donor community (World Bank, UNDP, and UK DfiD) and the three local statistical agencies. Some 5,400 households (corresponding to about 9,400 individuals) were interviewed in 2001, about half of which have been interviewed each year through 2004 . The sampling frame provided representative data at the national level, for each of the two entities that constitute Bosnia and Herzegovina (FBiH and RS), and by type of municipality (World Bank 2003).

The LSMS, as is typical of multi-topic surveys, includes multiple modules and collects information from households and individuals on their income and consumption behavior, labor market activity, educational attainment or current enrollment, health status and health care utilization, and others. This note uses the labor market module covering individuals' labor market status, job search behavior, occupation and industry of employment, and wage levels. Survey responses to questions on employment and job search behavior (i.e., whether an individual has been looking for work over the reference period and whether he/she is ready to work in two weeks) allow for the calculation of unemployment consistent with the ILO definition, except in the 2003 wave, where ILOconsistent unemployment indicators could not be computed due to "routing error." For estimating labor market dynamics, data are drawn from each of the four waves using a total common sample of 6,360 individuals, although the samples of working-age individuals and working-age individuals currently in the labor force are of course much lower. We use both panel weights and wave-specific weights, as appropriate, but the results are invariant to weighting. 
Table 2. Descriptive Statistics: Bosnia and Herzegovina, 2001-2004

(In units as indicated)

\begin{tabular}{|c|c|c|c|c|c|c|}
\hline & \multicolumn{3}{|c|}{$\begin{array}{l}\text { In percent } \\
\text { of the labor force }\end{array}$} & \multicolumn{3}{|c|}{$\begin{array}{l}\text { In percent } \\
\text { of the working age population }\end{array}$} \\
\hline & 2001 & 2002 & 2004 & 2001 & 2002 & 2004 \\
\hline Men & 65 & 64 & 63 & 49 & 49 & 50 \\
\hline \multicolumn{7}{|l|}{ Age Groups } \\
\hline Age 15-24 & 14 & 15 & 15 & 22 & 23 & 19 \\
\hline Age $25-44$ & 52 & 51 & 50 & 41 & 40 & 41 \\
\hline Age 45-54 & 26 & 25 & 26 & 21 & 21 & 23 \\
\hline Age 55+ & 8 & 9 & 9 & 17 & 17 & 17 \\
\hline \multicolumn{7}{|l|}{ Educational Attainment } \\
\hline Unfinished Elementary & 7 & 7 & 6 & 13 & 13 & 12 \\
\hline Elementary & 21 & 22 & 22 & 31 & 31 & 28 \\
\hline Vocational & 42 & 40 & 38 & 32 & 31 & 31 \\
\hline High School & 20 & 21 & 24 & 18 & 19 & 23 \\
\hline College (2+ years) & 5 & 4 & 4 & 3 & 3 & 3 \\
\hline University & 5 & 5 & 5 & 3 & 3 & 3 \\
\hline Unemployment Rate & 16 & 22 & 22 & & & \\
\hline Labor Force Participation & & & & 48 & 53 & 59 \\
\hline
\end{tabular}

Source: LSMS and authors' calculations.

Table 2 reports selected descriptive statistics of the sample used in our empirical analysis. The distributions of age, gender and skills are presented for each year (2001, 2002 and 2004). The labor force participation rate increased from 40 percent in 2001 to 59 percent in 2004. Despite this increase, the participation rate in Bosnia and Herzegovina is low compared to other ECA countries, mostly due to the very low labor force participation rate among women. Average unemployment rate is high, and increased from 16 percent in 2001 to 22 percent in 2004. The characteristics of the work force (and the working population) are fairly stable, where youth represent around 22 percent of the working population (the decline from 2001 to 2004 is due to the ageing for the panel). The educational attainment is relatively high, with over 70 percent with vocational education, secondary education or more. Interestingly the level of secondary education has increased significantly over the sample years, offset by a corresponding decrease in vocational education.

What do we know of youth labor market transitions in the ECA region? Appendix Table 1 reports summary data on labor market transition from selected countries in the region, including Bulgaria, Estonia, Poland, Russia and Turkey where panel data are available and allow us a systematic examination of the labor market experience of 
younger workers. There are three main observations on labor market transition dynamics based on Appendix Table 1:

- Young people have high persistent unemployment spells. In Bulgaria more than 57 percent (63 percent) of males (females) less than 30 years of age remained unemployment between 1991 and 1992. In Poland, two-thirds of the young unemployed in 2000 were found to remain unemployed 4 years after.

- The youth who are employed are more likely than adults to leave employment and become either unemployed or out of the labor force. In Poland, those aged 15 to 24 are twice more likely to become unemployed, while in Turkey, employed youth are more than 50 percent more likely to become unemployed relative to their adult counterparts.

- Finally, the youth, particularly young women, are more likely to become discouraged and leave the labor force completely. In Turkey, more that 90 percent of young women were like to leave the workforce between 2000 and 2001.

\section{Empirical Findings}

\section{A. Early transitions}

In Bosnia and Herzegovina, despite the end of the civil conflict in the late 1990s, the youth have had significant difficulties entering the labor market and have experienced excessive instability in their early years of the transition to work. In 2004, the unemployment rate was 62 percent for those between 15-19 years old, and 37 percent for those between 20-24 years old, compared to 22 percent for adults in the same year.

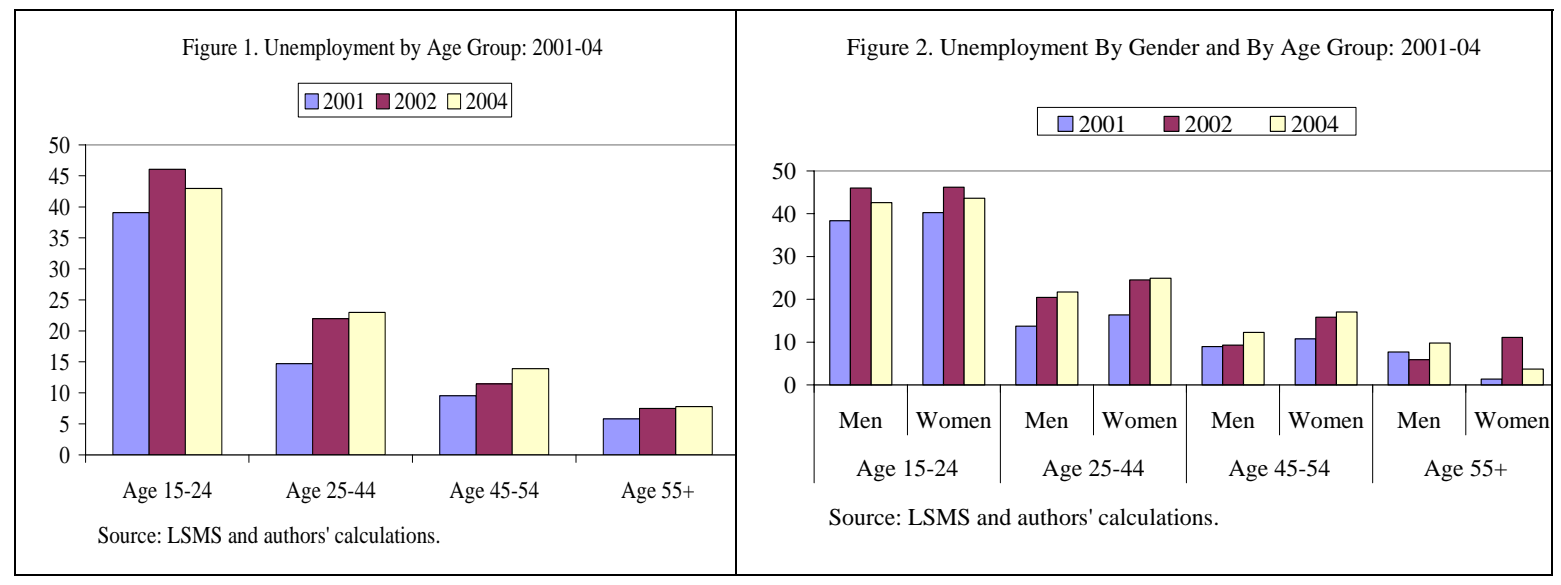

Combining the 15-19 and 20-24 age groups together, the youth unemployment rate is higher than any other age group (Figure 1). On average, it is about twice the aggregate unemployment rate, although the disparity has narrowed somewhat over time. 
Across all age groups, women consistently experience higher unemployment rates than men (Figure 2). Among the youth, female unemployment rates have been over 40 percent between 2001 and 2004.

Table 3 reports the labor market transition probabilities for working-age individuals in Bosnia and Herzegovina, between 2001 and 2002 and between 2001 and 2004. The columns represent the labor market outcomes in 2002 and 2004 for each of the labor market states in 2001. These outcomes persist in the first few years of youth experience in the labor market. Among those 15-24 who where unemployed in 2001, 77 percent were jobless one year later, and 58 percent were still jobless three years later. Even among youth employed in 2001, a third of them were jobless in 2002, and a quarter of them were still jobless in 2004.

Table 3. Panel Estimates of Transition Probabilities in Bosnia and Herzegovina, 2001-2004

\begin{tabular}{|c|c|c|c|c|c|c|}
\hline & \multicolumn{3}{|c|}{ Employment status in 2002} & \multicolumn{3}{|c|}{ Employment status in 2004} \\
\hline & Inactive & Unemployed & Employed & Inactive & Unemployed & Employed \\
\hline \multicolumn{7}{|c|}{ Employment Status in 2001} \\
\hline \multicolumn{7}{|c|}{ All } \\
\hline Inactive & 73.3 & 12.4 & 14.3 & 63.3 & 15.3 & 21.3 \\
\hline Unemployed & 32.3 & 33.7 & 33.9 & 30.0 & 27.4 & 46.6 \\
\hline All employed & 13.0 & 6.9 & 80.6 & 12.9 & 8.3 & 78.7 \\
\hline \multicolumn{7}{|l|}{ Ages $15-24$} \\
\hline Inactive & 71.0 & 16.6 & 12.4 & 53.4 & 21.2 & 25.5 \\
\hline Unemployed & 36.3 & 40.3 & 23.5 & 25.8 & 32.3 & 41.9 \\
\hline All employed & 20.3 & 13.5 & 66.3 & 11.4 & 15.2 & 73.4 \\
\hline
\end{tabular}

Source : LSMS and authors' calculations.

In general, this does not compare favorably with other economies in transition, where flows out of joblessness among young workers are much larger (see Appendix Table 1). For example, in Estonia in the mid-1990s, close to half of all unemployed workers found employment the following year. In Russia, over this same period, over 40 percent moved out of unemployment. The flow of young workers out of unemployment in Poland, however, is comparable to that of Bosnia and Herzegovina.

Because transitions patterns are also affected by other individual characteristics, like educational attainment, marital status and geographic location, it is important to examine to what extent the conclusions from Table 3 remain valid once we control for these factors. Figure 3, for example, illustrates how among males, the unemployment rate for both skilled and unskilled workers decreases with age. However, among the youngest workers, the average unemployment rate of skilled men is higher than that of less skilled men. As age increases, the average unemployment rate among of skilled workers falls more rapidly that that of the less skilled workers. At age 35-44, for example, the unemployment rate of skilled workers is substantially lower than that of the less skilled workers. Figure 4 shows a similar breakdown of unemployment rates by skill 
or education level, and by age. Compared to Figure 3, Figure 4 suggests that the unemployment rate among females is higher than among males, across age groups and skill levels. In addition, while unemployment falls with age, skilled women do not have perceptibly lower unemployment rates than less skilled women. In the case of women in the labor force, then, there is some evidence that education does not confer as much advantage as it does to men.

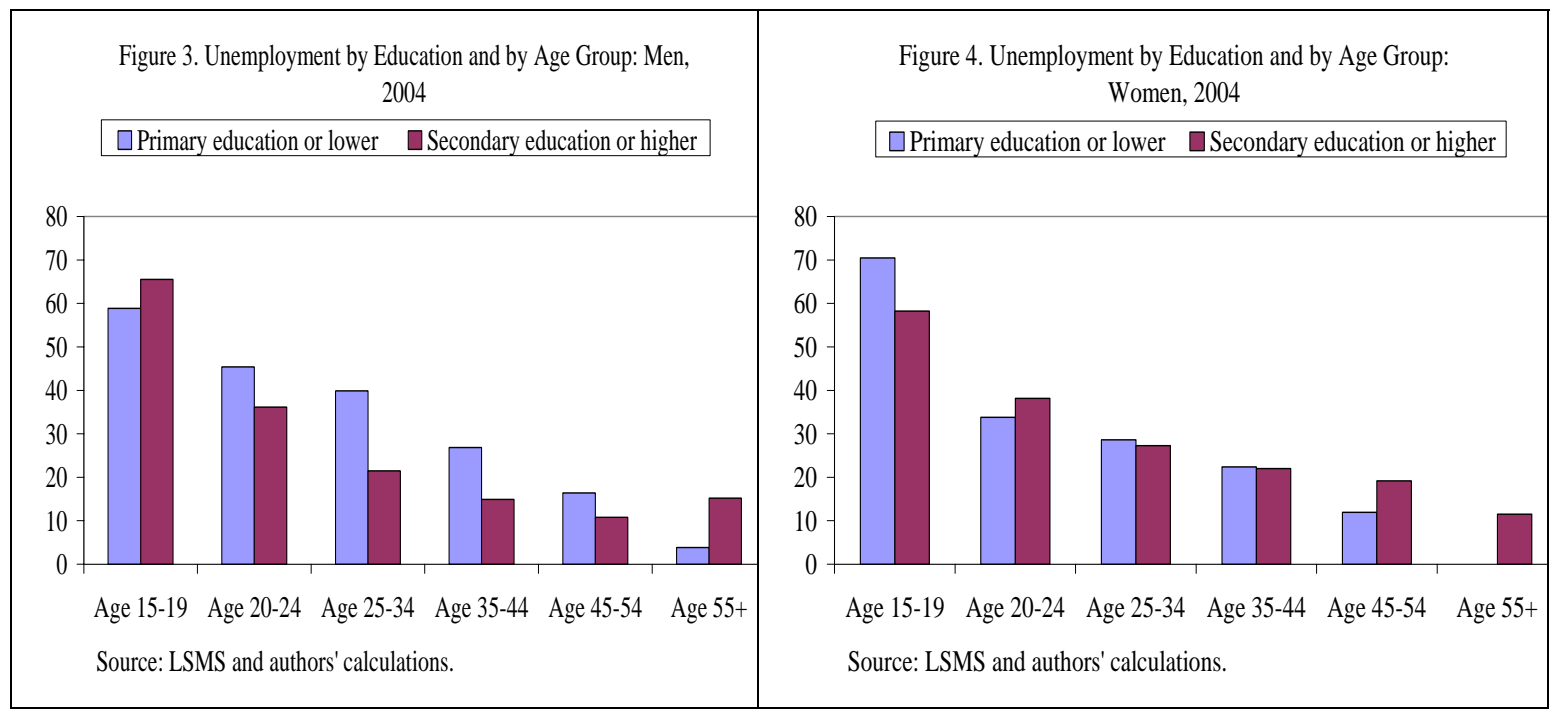

To properly account for observable individual characteristics, we report the results of a multivariate model. Appendix Table 2, reproduced from Tiongson and Yemtsov (2006) reports the results of a multinomial logit model of labor market transitions between 2001 and 2002, and between 2001 and 2004. This specification follows those of previous models of transition probabilities (see for example Lauerova and Terrell 2002; Bukowskiy and Lewandowski, 2005). The results broadly confirm that there are significant differences in labor market transitions by gender, age, education, and geographic location. In particular, when compared to women, men are less likely to leave employment into inactivity, and those unemployed are more likely to access employment, while those out of the labor force are also more like to enter the labor force.

The results also suggest that education facilitates transitions into employment, reduce the likelihood of becoming unemployed, and lower the exit out of the labor force. These estimates are significant for year to year transitions, as well as over the 3 years period. The age differences remain consistent with earlier estimates. In particular, the results suggest that younger workers are more likely to go into inactivity or unemployment, holding other variables constant. They are also less likely to move out of inactivity into either employment or unemployment both in the short and medium term.

\section{B. The effect of early labor market experience on later outcomes}

What are the effects of experiencing jobless spells in 2001 and 2002 on employment outcomes in 2004? What are the effects of experiencing unemployment spells on earnings in 2004? Does the effect vary with among different groups? We use a 
simple probability model of employment or unemployment on observable characteristics and unemployment history to estimate the effect of early difficulties in the labor market on subsequent outcomes. Because of the panel structure of the data, individuals who experienced unemployment or jobless spells in 2001 could be traced in 2004 and their employment status is observed. For those who are employed in 2004, their wages are also observed.

Controlling for workers' characteristics, e.g. gender, age, education, marital status, and geographic location, those who suffered a spell of unemployment or inactivity at any point over the 2001-2002 period were also found to have faced a greater likelihood of unemployment or joblessness (both inactivity and unemployment) in 2004. Among young workers, the experience of joblessness is associated with about 11 percent greater probability of unemployment and 30 percent greater probability of joblessness. The effect on earnings is also significant. For all workers, in Bosnia and Herzegovina, a spell of joblessness is associated with lower wages.

\section{Labor Market Activity}

Table 4 and Appendix Tables 4 and 5 report probit regression results using the baseline model described in the previous section. In estimating the impact of previous labor market experience on subsequent outcomes, we test the baseline model using various sub-samples, including samples of younger workers only, of male workers, and younger male workers, to test the robustness of the results.

We use two measures of current and previous labor market activity: the first is a measure of unemployment and the second is a measure of joblessness. In particular, the dependent variable in Table 4 and Appendix Table 4 is a binary measure of unemployment; the regression results are thus based on a sample of individuals currently in the labor force. On the other hand, the dependent variable in Appendix Table 5 is a binary measure of joblessness (i.e., treating both the unemployed and those out of the labor force as "jobless") and the sample includes all working-age individuals. As for the measure of previous labor market experience, Table 4 uses a binary measure of previous unemployment, representing the experience of at least one unemployment spell, either in 2001 or 2002. Appendix Tables 4 and 5 use a binary measure of joblessness; this measure allows for the possibility of a jobless spell either in 2001 or 2002, or both.

The results suggest that between 2001 and 2004, young workers who suffered a spell of unemployment or joblessness (i.e., including either unemployment or inactivity) at any point over the 2001 to 2002 period also faced a greater likelihood of unemployment or joblessness in 2004. This is true for all workers as a group as well as for the subgroups of young workers or young male workers.

The magnitude of impact is not trivial. Among young workers, the experience of an unemployment spell is associated with about 11 percent greater probability of unemployment and 30 percent greater probability of joblessness (marginal effects are not shown) 
Table 4. Previous Unemployment Spell and the Probability of Unemployment in 2004

(Probit regression coefficients; t-statistics in parentheses; includes only those in the labor force)

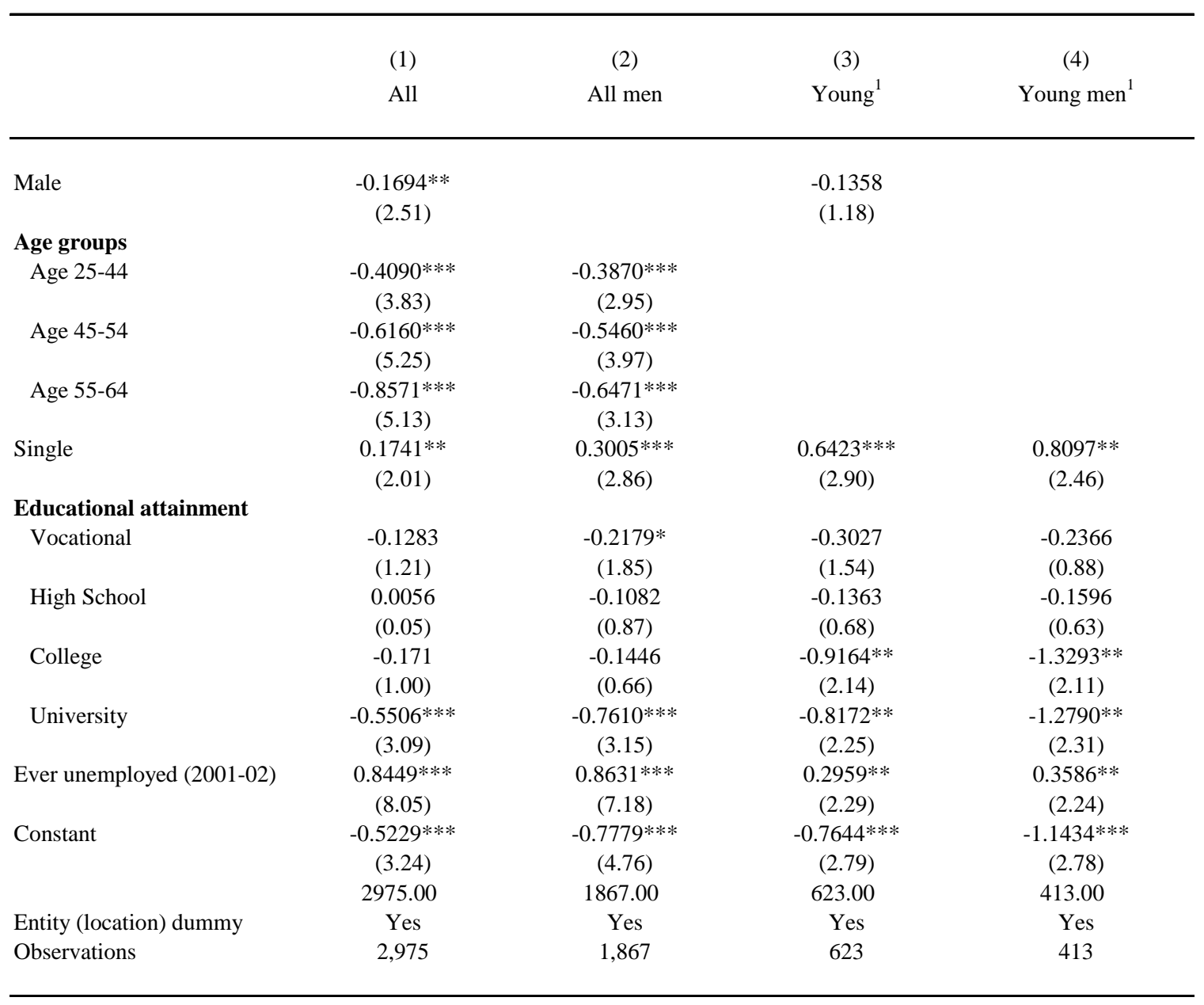

* significant at $10 \%$; ** significant at $5 \%$; *** significant at $1 \%$

Standard errors are corrected for stratification and intra-cluster correlation.

${ }^{1}$ Those who were in the 15-24 age bracket in 2001. 
Wages

For estimating wage effects, we use a simple wage regression model of the following form:

$$
\log \left(w_{i t}\right)=\alpha+\beta X_{i t}+\gamma Z_{i(t-1)}+\varepsilon_{i t}
$$

for individual $i$, at year $t=2004$. $X$ includes the usual characteristics of individual $i$, while $Z$ is a vector of indicators of labor market activities in the past 3 year period, including a previous spell of unemployment. We also examine whether there are important interactions between labor market outcomes and education, in general whether scarring is much more severe for less educated workers.

Table 5 reports the OLS regression results for earnings. The results are based on a standard Mincer regression where the log of wages is a function of age and age-squared (proxies of experience), educational attainment, and other control variables. Columns (1) to (3) use the full sample of employed individuals, progressively allowing for a fuller set of control variables. Column (3), for example, controls for both industry and sector of employment. Meanwhile, columns (4) to (6) use sub-samples similar to the previous tables.

One important issue in estimating this model is the lack of control for the likely endogeneity of the unemployment history. That is, it is usually argued that because being unemployed in any previous period might not be orthogonal to wage determination. In the context of this model, if some time-unobservable individual characteristics affect both employment status and wages, then the estimated effect of previous employment on wages might be biased. However, if most of the selection is driven by observable individual characteristics, the bias in the estimated effect on wage growth might not be very severe. Unfortunately, the relatively short time span covered by our panel data presents us from properly accounting for endogeneity. We thus restrict our analysis to a standard OLS earnings regression.

We are unable to establish, among young workers, any significant link between the previous experience of joblessness and future wage levels, although for all workers as a group, having suffered a spell of unemployment is correlated with lower wages. The impact can be considerable. The results suggest that the wage levels of those who were previously unemployed are some 10 percent lower than those of their counterparts, holding other things constant. 
Table 5. Earnings Regressions in 2004 By Selected Sub-Samples

(OLS regression coefficients; t-statistics in parentheses)

\begin{tabular}{|c|c|c|c|c|c|c|}
\hline & $\begin{array}{c}\text { (1) } \\
\text { All workers }\end{array}$ & $\begin{array}{c}\text { (2) } \\
\text { All workers }\end{array}$ & $\begin{array}{c}\text { (3) } \\
\text { All workers }\end{array}$ & $\begin{array}{c}\text { (4) } \\
\text { All male workers }\end{array}$ & $\begin{array}{c}\text { (5) } \\
\text { All young workers }{ }^{1}\end{array}$ & $\begin{array}{c}\text { (6) } \\
\text { All young male workers }{ }^{1}\end{array}$ \\
\hline Male & $\begin{array}{c}0.1959 * * * \\
(5.40)\end{array}$ & $\begin{array}{c}0.1821^{* * *} \\
(5.14)\end{array}$ & $\begin{array}{c}0.1671^{* * *} \\
(5.08)\end{array}$ & & $\begin{array}{l}0.0067 \\
(0.07)\end{array}$ & \\
\hline Age & $\begin{array}{c}0.0204^{*} \\
(1.72)\end{array}$ & $\begin{array}{c}0.0224 * \\
(1.94)\end{array}$ & $\begin{array}{c}0.0305 * * * \\
(2.95)\end{array}$ & $\begin{array}{c}0.0287^{*} \\
(1.92)\end{array}$ & & \\
\hline Age-squared & $\begin{array}{c}-0.0002^{*} \\
(1.69)\end{array}$ & $\begin{array}{c}-0.0003^{* *} \\
(1.98)\end{array}$ & $\begin{array}{c}-0.0004 * * * \\
(2.87)\end{array}$ & $\begin{array}{c}-0.0003^{*} \\
(1.95)\end{array}$ & & \\
\hline Single & $\begin{array}{l}0.03 \\
(0.74)\end{array}$ & $\begin{array}{l}(0.00) \\
(0.02)\end{array}$ & $\begin{array}{l}(0.00) \\
(0.03)\end{array}$ & $\begin{array}{l}(0.03) \\
(0.43)\end{array}$ & $\begin{array}{c}0.2913^{* *} \\
(2.46)\end{array}$ & $\begin{array}{l}0.33 \\
(1.35)\end{array}$ \\
\hline \multicolumn{7}{|l|}{ Educational attainment } \\
\hline Vocational & $\begin{array}{c}0.1178^{* * *} \\
(2.62)\end{array}$ & $\begin{array}{l}0.0674 \\
(1.51)\end{array}$ & $\begin{array}{l}0.0451 \\
(1.06)\end{array}$ & $\begin{array}{l}0.0575 \\
(1.19)\end{array}$ & $\begin{array}{c}0.2069^{*} \\
(1.70)\end{array}$ & $\begin{array}{c}0.2991^{* *} \\
(2.39)\end{array}$ \\
\hline High School & $\begin{array}{c}0.1667 * * * \\
(2.90)\end{array}$ & $\begin{array}{c}0.1151^{* *} \\
(2.17)\end{array}$ & $\begin{array}{c}0.1027^{* *} \\
(2.06)\end{array}$ & $\begin{array}{l}0.1059 \\
(1.56)\end{array}$ & $\begin{array}{l}0.0638 \\
(0.45)\end{array}$ & $\begin{array}{l}0.0806 \\
(0.49)\end{array}$ \\
\hline College & $\begin{array}{c}0.3218^{* * *} \\
(4.42)\end{array}$ & $\begin{array}{c}0.2903^{* * * *} \\
(3.76)\end{array}$ & $\begin{array}{c}0.2905 * * * \\
(3.91)\end{array}$ & $\begin{array}{l}0.1394 \\
(1.51)\end{array}$ & $\begin{array}{l}0.0705 \\
(0.55)\end{array}$ & $\begin{array}{l}0.123 \\
(0.99)\end{array}$ \\
\hline University & $\begin{array}{c}0.6900 * * * \\
(9.26)\end{array}$ & $\begin{array}{c}0.6332 * * * \\
(9.45)\end{array}$ & $\begin{array}{c}0.6283^{* * *} \\
(9.29)\end{array}$ & $\begin{array}{c}0.5494^{* * * *} \\
(5.70)\end{array}$ & $\begin{array}{c}0.5445^{* * * *} \\
(3.83)\end{array}$ & $\begin{array}{c}0.5307^{* * *} \\
(3.24)\end{array}$ \\
\hline Ever unemployed (2001-02) & $\begin{array}{c}-0.1185^{* * *} \\
(2.60)\end{array}$ & $\begin{array}{c}-0.0985 * * \\
(2.16)\end{array}$ & $\begin{array}{c}-0.1016^{* *} \\
(2.39)\end{array}$ & $\begin{array}{c}-0.1380^{* *} \\
(2.59)\end{array}$ & $\begin{array}{l}-0.089 \\
(1.07)\end{array}$ & $\begin{array}{c}-0.0627 \\
(0.57)\end{array}$ \\
\hline Constant & $\begin{array}{c}5.4312 * * * \\
(21.02)\end{array}$ & $\begin{array}{c}5.1655 * * * \\
(18.61)\end{array}$ & $\begin{array}{c}5.0999 * * * \\
(21.08)\end{array}$ & $\begin{array}{c}5.5426^{* * * *} \\
(16.29)\end{array}$ & $\begin{array}{c}5.7227^{* * *} \\
(30.97)\end{array}$ & $\begin{array}{c}5.6215^{* * *} \\
(21.31)\end{array}$ \\
\hline Entity (location) dummy & Yes & Yes & Yes & Yes & Yes & Yes \\
\hline Industry dummies & No & Yes & Yes & No & No & No \\
\hline Sector dummies & No & No & Yes & No & No & No \\
\hline Observations & 1,816 & 1,798 & 1,797 & 1,208 & 305 & 205 \\
\hline R-squared & 0.16 & 0.22 & 0.28 & 0.13 & 0.15 & 0.14 \\
\hline
\end{tabular}

* significant at $10 \%$; ** significant at $5 \%$; *** significant at $1 \%$

Standard errors are corrected for stratification and intra-cluster correlation.

${ }^{1}$ Those who were in the 15-24 age bracket in 2001.

\section{Does the scarring effect vary with individual characteristics?}

The overall results from the previous analysis show that education and experience shelters workers form unemployment and improve earnings. The results also show that on average those who experience unemployment spells tend to have their wages and employment opportunities lower than others who have similar age and education characteristics but have more favorable employment histories.

To what extent there are differences across skills and age in the impact of previous bad outcomes on current employment and wage outcomes among workers in Bosnia and Herzegovina could be also be tested. The results in Tables 4 and 5 and Appendix Tables 4 and 5 imply that these effects are higher for adults than youth. This possibly reflects a larger loss of specific human capital among adults compared to young workers as previously found in the literature. 
We can also test the effects for different skills groups. To do so, a slight modification of the model estimated in the previous section could be used.

$$
\log \left(w_{i t}\right)=\alpha+\beta X_{i t}+\gamma Z_{i(t-1)} X_{i t}+\varepsilon_{i t}
$$

The interaction between the $\mathrm{X}$ and $\mathrm{Z}$ allows estimating the effect on previous unemployment spells on individuals with different skills. Table 6 shows the estimated coefficients for 3 different education levels: lower than primary, vocational and secondary, and post secondary education. The effect on wages and unemployment of either being ever unemployed or jobless is often large and significant. The penalty is highest among the most educated. Among those with post secondary education, experiencing an adverse employment shock reduces future wages by 30 percent. The effect on future unemployment also becomes steeper for those with high skills compared to low educational attainment.

The results suggest that some strong signaling effect could be in play. Experiencing unemployment among highly educated workers could reveal poor quality, compared to unemployment among low skilled that might be subject to less selection.

Table 6. Unemployment Scar by Education Group: Impact on Unemployment and Wages (Coefficient estimates from earnings regression and probit regression)

\begin{tabular}{|c|c|c|c|c|}
\hline & \multicolumn{2}{|c|}{ Impact on Wages (OLS) } & \multicolumn{2}{|c|}{ Impact on Unemployment (Probit } \\
\hline & Ever Jobless & Ever Unemployed & Ever Jobless & $\overline{\text { Ever Unemployed }}$ \\
\hline \multicolumn{5}{|l|}{ Educational attainment } \\
\hline Unfinished primary and primary education & $\begin{array}{c}-0.1273 \\
(1.45)\end{array}$ & $\begin{array}{c}-0.1115 \\
(1.40)\end{array}$ & $\begin{array}{c}1.2043^{* * *} \\
(7.39)\end{array}$ & $\begin{array}{c}0.9289 * * * \\
(5.52)\end{array}$ \\
\hline Vocational and secondary education & $\begin{array}{c}-0.1059 * \\
(1.87)\end{array}$ & $\begin{array}{c}-0.1454 * * * \\
(2.96)\end{array}$ & $\begin{array}{c}1.2377^{* * * *} \\
(12.65)\end{array}$ & $\begin{array}{c}0.7549 * * * \\
\quad(6.62)\end{array}$ \\
\hline College and university education & $\begin{array}{c}-0.2868 * * * \\
(3.45)\end{array}$ & $\begin{array}{c}-0.1885^{* *} \\
(2.01)\end{array}$ & $\begin{array}{c}1.7337^{* * * *} \\
(6.10)\end{array}$ & $\begin{array}{c}1.1470 * * * \\
(3.69)\end{array}$ \\
\hline
\end{tabular}

T statistics in parentheses. Standard errors are corrected for stratification and intra-cluster correlation.

* significant at $10 \%$; ** significant at $5 \%$; *** significant at $1 \%$

\section{Concluding Observations}

The stylized facts on youth unemployment have been drawn mostly from labor market experiences in advanced economies. Relatively less is known about scarring in transition economies, despite a difficult transition period over the last decade and despite the prominence of labor market adjustment issues in these economies. Furthermore, little is known about the lasting consequences of unemployment and inactivity in these countries. This has been due in large part to the relative scarcity of longitudinal data. In 
this paper, we use panel data from Bosnia and Herzegovina to examine youth unemployment over the 2001 to 2004 period.

Three main conclusions are supported by this analysis:

First, it is clear that young people face several barriers in transition to work in Bosnia and Herzegovina, consistent with recent findings reported (World Bank 2006). This difficulty is reflected in high incidence of unemployment among youth compared to adults. It is also reflected in long duration in the transition from school to work. Younger workers are also more likely to go into inactivity or unemployment or are less likely to transition out of inactivity, holding other things constant.

Second, initial spells of unemployment or joblessness appear to have lasting unfavorable effects. Early difficulties in the transition to work have dynamic implications and could reduce the ability to better integrate youth into the labor market. The micro evidence indicates that the experience of joblessness raises the probability of experiencing another spell by up to 30 percent even after 2 years despite controlling for age, education, marital status and location. Being previously unemployed also lowers future wages by an average 10 percent. There is no evidence, however, that the youth are at a greater risk of scarring, or suffer disproportionately worse outcomes from initial spells of unemployment and joblessness, compared to other age groups. If anything, the wage and unemployment scar may be larger in magnitude for much older workers.

Third, educational attainment is generally associated with more favorable labor market outcomes. Educated workers are less likely to be jobless and are less likely to transition from employment into joblessness. However, the penalty from jobless spells may also be higher for more educated workers. We speculate that this may be due to stigma or signaling, consistent with previous findings. 


\section{References}

Audas, Rick, Eva Berde, and Peter Dolton. 2005. "Youth Unemployment and Labour Market Transitions in Hungary,” Education Economics, Vol. 13, No. 1 (March): $1-25$.

Blanco, Almudena and Juchen Kluve. 2002. "Why not stay at home: Nest leaving behavior in Western Europe,” (Berkeley: University of California, Berkeley).

Boeri, Tito and Katherine Terrell. 2002. "Katherine Institutional Determinants of Labor Reallocation in Transition,” Journal of Economic Perspectives Vol. 16, No. 1 (Winter 2002): pp. 51-76.

Borgarello, Andrea, Susan Duryea, Olgiati Scarpetta and Stefano Scarpetta. 2005. "Early experiences of youths in the labor market: stepping stones or traps?” (Washington: The World Bank).

Bukowski, Maciej and Piotr Lewandowski. 2005a. "Transitions from unemployment in Poland: a multinomial logit analysis,” mimeo (Warsaw: Warsaw School of Economics).

. 2005b. "Transitions from employment in Poland: a multinomial logit analysis," mimeo (Warsaw: Warsaw School of Economics).

Burgess, Simon, Carol Propper, Hedley Rees, and Arran Shearer. 2003. "The Class of 1981: The Effects of Early Career Unemployment on Subsequent Unemployment Experiences.” Labour Economics Vol. 10: 291-309.

Card, David, and Thomas Lemieux. 2000. “Adapting to Circumstances: The Evolution of Work, School, and Living Arrangements among North American Youth,” in The Youth Labor Market Problem: Its Nature, Causes and Consequences, Freeman and Wise, eds. (Chicago: NBER and University of Chicago Press).

Corcoran, Mary. 1982. “The Employment and Wage Consequences of Teenage Women’s Nonemployment,” in The Youth Labor Market Problem: Its Nature, Causes and Consequences, Freeman and Wise, eds. (Chicago: NBER and University of Chicago Press).

Doiron, Denise. 1995. “Lay offs as signals: The Canadian evidence,” The Canadian Journal of Economics, Vol. 28, No 4a (November): 899-913.

Ellwood, David. 1982. “Teenage Unemployment: Permanent Scars or Temporary Blemishes?” in The Youth Labor Market Problem: Its Nature, Causes and Consequences, Freeman and Wise, eds. (Chicago: NBER and University of Chicago Press). 
Eamets, Raul. 2004. "Labour Market Flows and Adjustment to Macroeconomic Shocks in the Baltic States,” Post-Communist Economies Vol. 16, No. 1 (March): 47-71.

Gibbons, R. and L.F. Katz. 1991. "Layoffs and Lemons,” Journal of Labour Economics, Vol. 9: $351-80$.

Gregory, Mary and Robert Jukes. 2001. "Unemployment and subsequent earnings: Estimating scarring among British men 1984 - 94.” The Economic Journal, Vol. 111 (November): F607 - F625.

Gregg, Paul. 2001. "Unemployment Scarring: The Impact of Youth Unemployment on Adult Unemployment in the NCDS," The Economic Journal, Volume 111, Issue 475: F626-F653.

Gregg, Paul and Emma Tominey. 2004. "The Wage Scar from Youth Unemployment,” CMPO Working Paper Series No. 04/097. . 2005. “The wage scar from male youth unemployment,” Labour Economics, Vol. 12: 487-509.

Hyytinen, Ari and Petri Rouvinen. 2006. "The Labour Market Consequences of Self Employment Spells: European Evidence,” European University Institute Working Paper No. 2006/08.

ILO, 2004. “Global Employment Trends for Youth.” Geneva: International Labour Office.

Inter-American Development Bank. 2004. Economic and social progress in Latin America: 2004 report: Good jobs wanted: Labor markets in Latin America (Washington: Johns Hopkins University Press).

Jacobson, L., LaLonde, R. and Sullivan, D. 1993. "Earning Losses of Displaced Workers", American Economic Review, Vol. 83, No. 4, pp. 685-709.

Jones, Derek C. and Takao Kato. 1997. "The Nature and the Determinants of Labor Market Transitions in Former Communist Economies: Evidence from Bulgaria," Industrial Relations, Vol. 36, No. 2 (April): 229-54.

Kletzer, Lori G., and Robert W. Fairlie. 2003. "The Long-Term Costs of Job Displacement for Young Adult Workers.” Industrial and Labor Relations Review Vol. 56, No. 4: 682-98.

Kolev, Alexandre and Catherine Saget. 2005. "Towards a Better Understanding of the Nature, Causes and Consequences of Youth Labor Market Disadvantage: Evidence for South-East Europe,” Social Protection Discussion Paper No. 0502 (Washington: The World Bank). 
Kollo, Janos and Gyula Nagy. 1996. "Earning Gains and Losses from Insured Unemployment in Hungary,” Labour Economics, Vol. 3: 279-298.

Lauerová, Jana Stefanová and Katherine Terrell. 2002. “Explaining Gender Differences in Unemployment with Micro Data on Flows in Post-Communist Economies," IZA Discussion Paper No. 600 (Bonn: Institute for the Study of Labor).

Light, Audrey and Kathleen McGarry. 1998. "Job Change Patterns and the Wages of Young Men,” Review of Economics and Statistics, Vol. 80, No. 2 (May): 276-286.

Lupi, Claudio and Patrizia Ordine 2002. "Unemployment scarring in high unemployment regions,” Economics Bulletin, Vol. 10, No 2: 1-8.

OECD. 1998. "Getting started, settling in: the transition from education to the labour market,” Employment Outlook, June: 81-122.

. 2005. From Education to Work: A Difficult Transition for Young Adults with Low Levels of Education (Paris: OECD).

O’Higgins, Niall. 2004. "Recent Trends in Youth Labour Markets and Youth Employment Policy in Europe and Central Asia,” Discussion Paper No. 85, Università degli Studi di Salerno, Centro di Economia del Lavoro e di Politica Economica.

Ryan, Paul (2001) “The school to work transition: A cross national perspective.” Journal of Economic Literature, 39(1): 34 - 92.

Tasci, H. Mehmet and Aysit Tansel. 2005. "Unemployment and Transitions in the Turkish Labor Market: Evidence from Individual Level Data,” IZA Discussion Paper No. 1663 (Bonn: The Institute for the Study of Labor).

Tiongson, Erwin and Ruslan Yemtsov, 2006, "Poverty and the Labor Market in Bosnia and Herzegovina: 2001 to 2004,” mimeo (Washington: The World Bank).

Topel, Robert H. 1990. "Specific Capital and Unemployment: Measuring the Costs and Consequences of Job Loss.” Carnegie-Rochester Conference Series on Public Policy Vol. 33:181-214.

Topel, Robert H. and Michael P. Ward. 1992. "Job Mobility and the Careers of Young Men,” The Quarterly Journal of Economics, Vol. 107, No. 2 (May): 439-479.

World Bank, 2002, "Labor Market in Postwar Bosnia and Herzegovina: How to Encourage Businesses to Create Jobs and Increase Worker Mobility” Report No. 24889-BIH (Washington: The World Bank). 
, 2003, “Bosnia and Herzegovina: Poverty Assessment,” Report No. 25343-BIH (Washington: The World Bank).

, 2005, “Bosnia and Herzegovina: Country Economic Memorandum,” Report No. 29500-BA (Washington: The World Bank).

, 2006, "Bosnia and Herzegovina: Labor market update: the role of industrial relations,” Report No. 32650-BA (Washington: The World Bank). 
Appendix Table 1. Transition Probabilities By Age

\begin{tabular}{|c|c|c|c|c|c|c|c|c|c|c|}
\hline \multirow[b]{2}{*}{ Country } & \multirow[b]{2}{*}{ Year } & \multicolumn{3}{|c|}{ Employment to } & \multicolumn{3}{|c|}{ Unemployment to } & \multicolumn{3}{|c|}{ Labor Force to } \\
\hline & & Employment & Out of Labor Force & $\overline{\text { Unemployment }}$ & Employment & Out of Labor Force & Unemployment & Employment & Unemployment & Out of Labor Force \\
\hline Bulgaria & 1991-1992 & & & & & & & & & \\
\hline All & & & & & 36.9 & 3.1 & & & & \\
\hline Men, age 30 or younger & & & & & 42.5 & 0.0 & 57.5 & & & \\
\hline Women, age 30 or younger & & & & & 33.3 & 3.6 & 63.1 & & & \\
\hline Estonia & 1994 & & & & & & & & & \\
\hline All & & & 6.0 & 5.0 & 41.0 & 12.0 & & 12.0 & 3.0 & \\
\hline Men, age 15-24 & & 83.7 & 8.8 & 7.5 & 48.6 & $16.2^{1}$ & 35.2 & 18.7 & 6.8 & 74.5 \\
\hline Women, age 15-24 & & 81.2 & 4.5 & 14.3 & 47.6 & $28.5^{1}$ & 23.9 & 18.6 & 10.3 & 71.1 \\
\hline Poland & 1997-2004 & & & & & & & & & \\
\hline All & & & 3.6 & 3.2 & 22.9 & 14.5 & & & & \\
\hline Age $15-24$ & & 85.9 & 5.5 & 8.6 & 27.4 & 11.6 & 61.0 & & & \\
\hline Poland & 2000-2004 & & & & & & & & & \\
\hline All & & & & & 19.4 & 13.8 & & & & \\
\hline Age $15-24$ & & & & & 22.7 & 11.2 & 66.1 & & & \\
\hline Russia & 1995-1996 & & & & & & & & & \\
\hline All & & & 6.2 & 5.6 & 39.5 & 14.5 & & 7.6 & 3.4 & \\
\hline Age $18-24$ & & 81.3 & 8.9 & 9.8 & 41.4 & 18.0 & 40.6 & 20.1 & 12.5 & 67.4 \\
\hline Turkey & $2000-2001$ & & & & & & & & & \\
\hline All & & & 17.0 & 3.5 & 45.7 & 8.1 & & 11.6 & 2.3 & \\
\hline Age 15-19 & & 58.2 & 35.0 & 6.8 & 30.9 & 15.5 & 53.6 & 11.8 & 3.3 & 85.0 \\
\hline Age $20-24$ & & 72.3 & 22.1 & 5.6 & 47.7 & 7.8 & 44.5 & 12.5 & 4.8 & 82.7 \\
\hline Men, age 15-19 & & 69.6 & 23.7 & 6.7 & 41.7 & 15.0 & 43.3 & 16.6 & 4.3 & 79.2 \\
\hline Men, age 20-24 & & 78.5 & 14.1 & 7.4 & 59.5 & 1.3 & 39.2 & 24.0 & 12.0 & 63.9 \\
\hline Women, age $15-19$ & & 49.3 & 41.7 & 9.0 & 12.9 & 6.5 & 80.7 & 6.6 & 2.4 & 91.0 \\
\hline Women, age 20-24 & & 68.2 & 28.7 & 3.1 & 25.0 & 10.0 & 65.0 & 7.2 & 2.4 & 90.4 \\
\hline
\end{tabular}

Sources: Bulgaria - Jones and Kato (1997); Estonia - Eamets (2001); Poland (1997-2004) - Bulowski and Landowski (2005a, 2005b); Russia - Foley (1997); Turkey - Tasci and Tansel (2005)

${ }^{1}$ Small sample size. 
Appendix Table 2. Multinomial Logit Model: Labor Market Transitions: 2001-2002 (Standard errors in parentheses)

\begin{tabular}{|c|c|c|c|c|c|c|}
\hline & \multicolumn{2}{|c|}{ Employment Transitions } & \multicolumn{2}{|c|}{ Unemployment Transitions } & \multicolumn{2}{|c|}{ Inactivity Transitions } \\
\hline & to Inactivity & to Unemployment & to Inactivity & to Employment & to Unemployment & to Employment \\
\hline Men & $\begin{array}{c}-0.815^{* * *} \\
(0.165)\end{array}$ & $\begin{array}{c}0.278 \\
(0.229)\end{array}$ & $\begin{array}{c}-0.926 * * \\
(0.432)\end{array}$ & $\begin{array}{c}0.823^{* *} \\
(0.350)\end{array}$ & $\begin{array}{c}0.779 * * * \\
(0.157)\end{array}$ & $\begin{array}{c}0.892 * * * \\
(0.174)\end{array}$ \\
\hline \multicolumn{7}{|l|}{ Age (years) } \\
\hline $25-44$ & $\begin{array}{c}-0.951 * * * \\
(0.315)\end{array}$ & $\begin{array}{l}-0.472 \\
(0.329)\end{array}$ & $\begin{array}{l}-0.200 \\
(0.325)\end{array}$ & $\begin{array}{c}0.328 \\
(0.409)\end{array}$ & $\begin{array}{l}0.542^{* *} \\
(0.263)\end{array}$ & $\begin{array}{c}1.100^{* * *} \\
(0.288)\end{array}$ \\
\hline $44-54$ & $\begin{array}{l}-0.630^{*} \\
(0.335)\end{array}$ & $\begin{array}{c}-1.333^{* * *} \\
(0.432)\end{array}$ & $\begin{array}{c}0.246 \\
(0.535)\end{array}$ & $\begin{array}{c}0.784 \\
(0.533)\end{array}$ & $\begin{array}{l}-0.118 \\
(0.288)\end{array}$ & $\begin{array}{c}0.953 * * * \\
(0.352)\end{array}$ \\
\hline $55+$ & $\begin{array}{c}0.290 \\
(0.340)\end{array}$ & $\begin{array}{c}-1.442^{* *} \\
(0.610)\end{array}$ & $\begin{array}{l}2.410^{* *} \\
(1.201)\end{array}$ & $\begin{array}{c}1.783 \\
(1.310)\end{array}$ & $\begin{array}{c}-2.616^{* * *} \\
(0.421)\end{array}$ & $\begin{array}{l}-0.269 \\
(0.399)\end{array}$ \\
\hline Single & $\begin{array}{c}0.146 \\
(0.262)\end{array}$ & $\begin{array}{c}0.708^{* * *} \\
(0.244)\end{array}$ & $\begin{array}{c}0.121 \\
(0.341)\end{array}$ & $\begin{array}{c}-0.821 * * \\
(0.346)\end{array}$ & $\begin{array}{c}0.269 \\
(0.247)\end{array}$ & $\begin{array}{c}0.374 \\
(0.308)\end{array}$ \\
\hline \multicolumn{7}{|l|}{ Education } \\
\hline Vocational & $\begin{array}{c}-0.657 * * * \\
(0.213)\end{array}$ & $\begin{array}{l}-0.333 \\
(0.257)\end{array}$ & $\begin{array}{l}-0.070 \\
(0.347)\end{array}$ & $\begin{array}{l}-0.080 \\
(0.352)\end{array}$ & $\begin{array}{c}1.205^{* * *} \\
(0.203)\end{array}$ & $\begin{array}{c}0.771 * * * \\
(0.172)\end{array}$ \\
\hline High School & $\begin{array}{c}-0.547^{*} \\
(0.324)\end{array}$ & $\begin{array}{c}-0.703^{* *} \\
(0.282)\end{array}$ & $\begin{array}{c}0.057 \\
(0.453)\end{array}$ & $\begin{array}{c}0.172 \\
(0.425)\end{array}$ & $\begin{array}{c}0.646^{* * *} \\
(0.198)\end{array}$ & $\begin{array}{c}0.336 \\
(0.226)\end{array}$ \\
\hline College & $\begin{array}{c}-1.269 * * * \\
(0.411)\end{array}$ & $\begin{array}{c}-1.070^{* *} \\
(0.539)\end{array}$ & $\begin{array}{c}-0.574 \\
(1.120)\end{array}$ & $\begin{array}{c}0.274 \\
(0.895)\end{array}$ & $\begin{array}{l}1.713^{* *} \\
(0.705)\end{array}$ & $\begin{array}{c}0.133 \\
(0.614)\end{array}$ \\
\hline University & $\begin{array}{c}-3.675^{* * *} \\
(1.038)\end{array}$ & $\begin{array}{c}-1.108^{* *} \\
(0.453)\end{array}$ & $\begin{array}{c}-33.627^{* * *} \\
(1.010)\end{array}$ & $\begin{array}{c}0.818 \\
(1.133)\end{array}$ & $\begin{array}{c}0.257 \\
(1.042)\end{array}$ & $\begin{array}{l}1.180^{* *} \\
(0.550)\end{array}$ \\
\hline Constant & $\begin{array}{c}-0.224 \\
(0.422)\end{array}$ & $\begin{array}{c}-1.873^{* * *} \\
(0.505)\end{array}$ & $\begin{array}{c}0.108 \\
(0.629)\end{array}$ & $\begin{array}{c}-0.191 \\
(0.669)\end{array}$ & $\begin{array}{c}-2.573^{* * *} \\
(0.392)\end{array}$ & $\begin{array}{c}-2.037 * * * \\
(0.380)\end{array}$ \\
\hline Number of Obs & & 2126 & & 422 & & 2439 \\
\hline
\end{tabular}

Source: Reproduced from Tiongson and Yemtsov (2006).

Note: The following are base groups: Female, 15-24 years of age, elementary or unfinished elementary school education, Banja Luka municipality. Standard errors are corrected for stratification and intra-cluster correlation. 
Appendix Table 3. Multinomial Logit Model: Labor Market Transitions: 2001-2004 (Standard errors in parentheses)

\begin{tabular}{|c|c|c|c|c|c|c|}
\hline & \multicolumn{2}{|c|}{ Employment Transitions } & \multicolumn{2}{|c|}{ Unemployment Transitions } & \multicolumn{2}{|c|}{ Inactivity Transitions } \\
\hline & to Inactivity & to Unemployment & to Inactivity & to Employment & to Unemployment & to Employment \\
\hline Men & $\begin{array}{c}-0.925 * * * \\
(0.159)\end{array}$ & $\begin{array}{c}0.285 \\
(0.207)\end{array}$ & $\begin{array}{c}-1.926^{* * *} \\
(0.440)\end{array}$ & $\begin{array}{l}-0.252 \\
(0.476)\end{array}$ & $\begin{array}{c}1.012^{* * *} \\
(0.163)\end{array}$ & $\begin{array}{c}1.166^{* * *} \\
(0.167)\end{array}$ \\
\hline \multicolumn{7}{|l|}{ Age (years) } \\
\hline $25-44$ & $\begin{array}{c}-0.484 \\
(0.300)\end{array}$ & $\begin{array}{c}-0.814^{* * *} \\
(0.283)\end{array}$ & $\begin{array}{c}0.341 \\
(0.398)\end{array}$ & $\begin{array}{c}0.065 \\
(0.371)\end{array}$ & $\begin{array}{c}0.645^{* * *} \\
(0.239)\end{array}$ & $\begin{array}{c}0.458 \\
(0.280)\end{array}$ \\
\hline $44-54$ & $\begin{array}{c}0.476 \\
(0.331)\end{array}$ & $\begin{array}{c}-1.130^{* * *} \\
(0.397)\end{array}$ & $\begin{array}{c}0.934 \\
(0.568)\end{array}$ & $\begin{array}{c}0.535 \\
(0.634)\end{array}$ & $\begin{array}{l}-0.538 * \\
(0.294)\end{array}$ & $\begin{array}{l}-0.267 \\
(0.289)\end{array}$ \\
\hline $55+$ & $\begin{array}{c}1.475^{* * *} \\
(0.386)\end{array}$ & $\begin{array}{c}-3.524^{* * *} \\
(1.090)\end{array}$ & $\begin{array}{c}24.235^{* * *} \\
(0.887)\end{array}$ & 22.287 & $\begin{array}{c}-3.163^{* * *} \\
(0.531)\end{array}$ & $\begin{array}{c}-1.459^{* * *} \\
(0.352)\end{array}$ \\
\hline Single & $\begin{array}{c}0.130 \\
(0.245)\end{array}$ & $\begin{array}{c}-0.118 \\
(0.231)\end{array}$ & $\begin{array}{c}-0.046 \\
(0.335)\end{array}$ & $\begin{array}{c}-0.553 \\
(0.379)\end{array}$ & $\begin{array}{c}0.748^{* * *} \\
(0.209)\end{array}$ & $\begin{array}{c}0.362 \\
(0.283)\end{array}$ \\
\hline \multicolumn{7}{|l|}{ Education } \\
\hline Vocational & $\begin{array}{c}-0.602 * * * \\
(0.189)\end{array}$ & $\begin{array}{l}-0.380 \\
(0.237)\end{array}$ & $\begin{array}{l}-0.030 \\
(0.373)\end{array}$ & $\begin{array}{l}1.190^{* *} \\
(0.457)\end{array}$ & $\begin{array}{l}0.428 * * \\
(0.168)\end{array}$ & $\begin{array}{c}0.818 * * * \\
(0.143)\end{array}$ \\
\hline High School & $\begin{array}{c}-1.141^{* * *} \\
(0.250)\end{array}$ & $\begin{array}{c}-0.782 * * \\
(0.317)\end{array}$ & $\begin{array}{c}0.428 \\
(0.464)\end{array}$ & $\begin{array}{c}0.761 \\
(0.516)\end{array}$ & $\begin{array}{c}0.113 \\
(0.208)\end{array}$ & $\begin{array}{c}0.478^{* *} \\
(0.184)\end{array}$ \\
\hline College & $\begin{array}{c}-0.944 * * * \\
(0.349)\end{array}$ & $\begin{array}{l}-0.328 \\
(0.395)\end{array}$ & $\begin{array}{l}-1.455 \\
(1.485)\end{array}$ & $\begin{array}{l}1.715^{*} \\
(0.996)\end{array}$ & $\begin{array}{c}2.277 * * * \\
(0.783)\end{array}$ & $\begin{array}{c}0.943 \\
(0.614)\end{array}$ \\
\hline University & $\begin{array}{c}-2.339 * * * \\
(0.484)\end{array}$ & $\begin{array}{c}-1.833^{* * *} \\
(0.532)\end{array}$ & $\begin{array}{c}-33.714^{* * *} \\
(1.308)\end{array}$ & $\begin{array}{c}0.766 \\
(1.134)\end{array}$ & $\begin{array}{c}0.487 \\
(0.939)\end{array}$ & $\begin{array}{l}0.780^{*} \\
(0.418)\end{array}$ \\
\hline Constant & $\begin{array}{c}-0.869 * * \\
(0.432)\end{array}$ & $\begin{array}{c}-0.783^{* *} \\
(0.388)\end{array}$ & $\begin{array}{c}1.162 \\
(0.905)\end{array}$ & $\begin{array}{c}0.821 \\
(0.781)\end{array}$ & $\begin{array}{c}-1.926 * * * \\
(0.341)\end{array}$ & $\begin{array}{c}-1.746^{* * *} \\
(0.342)\end{array}$ \\
\hline Number of Obs & & 2107 & & 421 & & 2306 \\
\hline
\end{tabular}

Source: Reproduced from Tiongson and Yemtsov (2006).

Note: The following are base groups: Female, 15-24 years of age, elementary or unfinished elementary school education, Banja Luka municipality. Standard errors are corrected for stratification and intra-cluster correlation. 
Appendix Table 4. Previous Jobless Spell and the Probability of Unemployment in 2004 (Probit regression coefficients; t-statistics in parentheses; includes only those in the labor force)

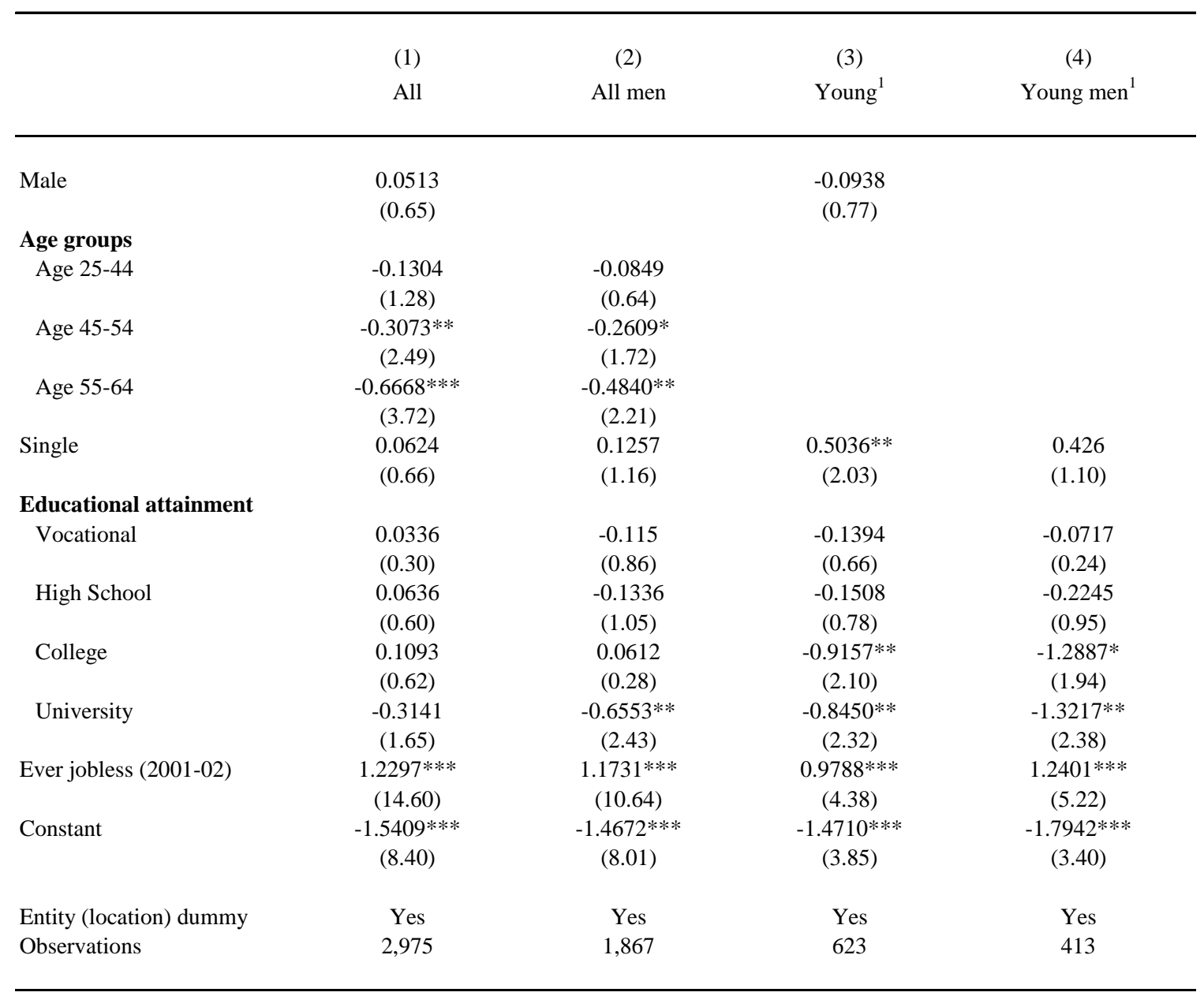

* significant at $10 \%$; ** significant at $5 \%$; *** significant at $1 \%$

Standard errors are corrected for stratification and intra-cluster correlation.

${ }^{1}$ Those who were in the 15-24 age bracket in 2001. 
Appendix Table 5. Previous Jobless Spell and the Probability of Joblessness in 2004

(Probit regression coefficients; t-statistics in parentheses; includes working-age population only)

\begin{tabular}{|c|c|c|c|c|}
\hline & $\begin{array}{l}(1) \\
\text { All }\end{array}$ & $\begin{array}{c}\text { (2) } \\
\text { All men }\end{array}$ & $\begin{array}{c}\text { (3) } \\
\text { Young }^{1}\end{array}$ & $\begin{array}{c}\text { (4) } \\
\text { Young men }\end{array}$ \\
\hline Male & $\begin{array}{c}-0.3982 * * * \\
(8.07)\end{array}$ & & $\begin{array}{c}-0.5165^{* * *} \\
(5.73)\end{array}$ & \\
\hline \multicolumn{5}{|l|}{ Age groups } \\
\hline Age 25-44 & $\begin{array}{c}-0.2721 * * * \\
(2.78)\end{array}$ & $\begin{array}{c}-0.2416^{*} \\
(1.93)\end{array}$ & & \\
\hline Age $45-54$ & $\begin{array}{l}-0.187 \\
(1.62)\end{array}$ & $\begin{array}{c}-0.1859 \\
(1.37)\end{array}$ & & \\
\hline Age 55-64 & $\begin{array}{c}0.3225^{* * *} \\
(2.67)\end{array}$ & $\begin{array}{c}0.3687 * * \\
(2.54)\end{array}$ & & \\
\hline Single & $\begin{array}{c}-0.0558 \\
(0.65)\end{array}$ & $\begin{array}{l}0.0763 \\
(0.81)\end{array}$ & $\begin{array}{l}0.1084 \\
(0.64)\end{array}$ & $\begin{array}{l}0.5215 \\
(1.30)\end{array}$ \\
\hline \multicolumn{5}{|l|}{ Educational attainment } \\
\hline Vocational & $\begin{array}{c}-0.1797 * * \\
(2.34)\end{array}$ & $\begin{array}{c}-0.2045^{*} \\
(1.90)\end{array}$ & $\begin{array}{c}-0.4167 * * * \\
(2.67)\end{array}$ & $\begin{array}{c}-0.4017^{*} \\
(1.68)\end{array}$ \\
\hline High School & $\begin{array}{c}-0.0898 \\
(1.27)\end{array}$ & $\begin{array}{l}-0.1512 \\
(1.56)\end{array}$ & $\begin{array}{c}-0.0423 \\
(0.30)\end{array}$ & $\begin{array}{c}-0.0985 \\
(0.58)\end{array}$ \\
\hline College & $\begin{array}{c}-0.2960^{* *} \\
(2.24)\end{array}$ & $\begin{array}{c}-0.0817 \\
(0.47)\end{array}$ & $\begin{array}{c}-1.0600^{* *} \\
(2.32)\end{array}$ & $\begin{array}{l}-0.9214 \\
(1.24)\end{array}$ \\
\hline University & $\begin{array}{c}-0.6096^{* * *} \\
(4.36)\end{array}$ & $\begin{array}{c}-0.5236^{* * *} \\
(2.88)\end{array}$ & $\begin{array}{c}-0.9490 * * * \\
(3.15)\end{array}$ & $\begin{array}{c}-0.8069 * * \\
(2.17)\end{array}$ \\
\hline Ever jobless (2001-02) & $\begin{array}{c}1.5874 * * * \\
(25.50)\end{array}$ & $\begin{array}{c}1.4307 * * * \\
(16.60)\end{array}$ & $\begin{array}{c}1.2955^{* * *} \\
(8.22)\end{array}$ & $\begin{array}{c}1.3848 * * * \\
(6.78)\end{array}$ \\
\hline Constant & $\begin{array}{c}-0.6310^{* * * *} \\
(4.39)\end{array}$ & $\begin{array}{c}-1.0533^{* * *} \\
(7.00)\end{array}$ & $\begin{array}{c}-0.4336 * \\
(1.77)\end{array}$ & $\begin{array}{c}-1.4596 * * * \\
(3.07)\end{array}$ \\
\hline Entity (location) dummy & Yes & Yes & Yes & Yes \\
\hline Observations & 4,832 & 2,442 & 1,119 & 599 \\
\hline
\end{tabular}

* significant at 10\%; ** significant at 5\%; *** significant at $1 \%$

Standard errors are corrected for stratification and intra-cluster correlation.

${ }^{1}$ Those who were in the 15-24 age bracket in 2001. 